\title{
Water Scarcity in Kenya: Current Status, Challenges and Future Solutions
}

\author{
Faith Mulwa ${ }^{1,2}$, Zhuo $\mathrm{Li}^{2,3 *}$, Fangnon Firmin Fangninou ${ }^{1,2}$ \\ ${ }^{1}$ UNEP-Tongji Institute of Environment for Sustainable Development, College of Environmental Science and Engineering, \\ Tongji University, Shanghai, China \\ ${ }^{2}$ State Key Laboratory of Pollution Control and Resource Reuse, College of Environmental Science \& Engineering, \\ Tongji University, Shanghai, China \\ ${ }^{3}$ Shanghai Institute of Pollution Control and Ecological Security, Shanghai, China \\ Email: faithmulwa@hotmail.com, firmin.fangninou@tongji.edu.cn, *zhuoli2013@tongji.edu.cn
}

How to cite this paper: Mulwa, F., Li, Z. and Fangninou, F.F. (2021) Water Scarcity in Kenya: Current Status, Challenges and Future Solutions. Open Access Library Journal, 8: e7096.

https://doi.org/10.4236/oalib.1107096

Received: December 18, 2020

Accepted: January 17, 2021

Published: January 20, 2021

Copyright $\odot 2021$ by author(s) and Open Access Library Inc.

This work is licensed under the Creative Commons Attribution International License (CC BY 4.0).

http://creativecommons.org/licenses/by/4.0/

\section{(c) (i) Open Access}

\begin{abstract}
Growing water demand and water scarcity have turned into a prominent challenge to livelihood in several parts worldwide. Global warming, water pollution, population growth, urbanization, and poor management of water resources have aggravated the issue of the water crisis. Water scarcity is expected to affect socio-economic activities, food security, education, health, and intensity climate change, hereby has caught the attention of the public. The United Nations Sustainable Development Goal (SDG) 6, Clean water and sanitation, sets various targets to make water sustainable for use by the year 2030. However, water scarcity assessment remains a challenge. Kenya, which has a growing population, is known as a water-scarce country due to its low supply of renewable freshwater $\left(<1000 \mathrm{~m}^{3} /\right.$ capita/year). Different initiatives are put in place to help in the mitigation and management of water resources. They include water policies to ensure the protection of water catchment areas, reduction of pollution as well as enhancing access to clean water and sanitation. This paper reviewed some of the water scarcity challenges in Kenya and potential future solutions.
\end{abstract}

\section{Subject Areas}

Hydrology

\section{Keywords}

Water Scarcity, Kenya, Water Resources, Indicators, Policy

\section{Introduction}

Water is an indispensable resource not only for sustaining all life but also for 
human socio-economic development. Global water demand is likely to surpass supply by more than $40 \%$ by 2030 and by more than $50 \%$ in the developing countries, especially in Sub-Saharan Africa [1]. Consequently, over four billion people are facing severe water scarcity at least one month annually, while half a billion people experience severe water scarcity throughout the year [2]. Furthermore, estimates show that by $2050,90 \%$ of the 3 billion people are expected to be added to the population of those who will be from developing countries and areas facing challenges of clean water and sanitation [3]. Population increase will eventually result in reduced per capita availability of water [4].

The water scarcity situation has worsened in most developing countries due to rapid population growth, economic development and urbanization which has made it so difficult to address the issue as well as providing adequate sanitation services [5]. A country is defined as water-stressed if the per capita water availability is below $1700 \mathrm{~m}^{3}$ per year. Kenya is among the water-scarce countries across the world with per capita availability below $1000 \mathrm{~m}^{3}$ annually [6]. The struggle for accessing clean and safe water is a problem experienced by more than 18 million people today. Previous studies indicate that only about $56 \%$ of the population has the access to a clean water supply [7]. Citizens mainly those in rural areas are forced to travel long distances of up to 8 miles to reach water that is highly polluted and even unsafe for human consumption [7].

The growth of Kenya's urban population and rapid urbanization of the rural areas is on the rise hence increasing domestic water demand, industrial and agricultural uses. However, challenges faced in the water sector, such as population pressure, water scarcity, climate change and water quality cannot be underestimated. To achieve the 2030 Agenda, water scarcity is a priority issue to be addressed [8]. The increasing rate of wastewater production with inadequate wastewater treatment resources and systems that are insufficient has led to effluent discharge into river systems. This not only leads to the degradation of downstream ecosystems but also causes health problems to humans [9]. There is a dire need for developing countries to shift from current water management practices to sustainable ways such as water reuse [10] as well as embarking on massive water development projects [11]. Population growth has caused an imbalance between water demand and supply in the country. This has led to a state of water crisis to the people hence incapable of meeting their water needs. However, policy frameworks are enacted to enhance management of the resources.

This paper reviews the status of management of water resources, some of the challenges of water scarcity in Kenya. We hypothesize that a better understanding of water scarcity is important because it affects both the users and policymakers regarding the urgency to address the water crisis as well as their views on the most effective policies to address the crisis. Therefore, we further examine future solutions in water management that will help in the improvement of the water sector, the policies and regulations set to ensure that water laws are adhered to. 


\section{Water Resources in Kenya}

Kenya's natural renewable water resources mainly rely on little and fragile catchments covered by the montane forests in the country's highland areas with a humid climate. The main five water towers in the country include Mt. Elgon, Cherangani Hills, Mau Forest Complex, Aberdare Ranges and Mt. Kenya. However, they are the main sources of many rivers in Kenya, feeding into major lakes, including Lake Victoria, Lake Nakuru, Lake Naivasha, Lake Baringo, Lake Natron, and Lake Turkana [12]. Kenya's water resources are considered to be unevenly distributed, both across and within as shown in Figure 1 [13]. The catchments contribute to over $75 \%$ of the nation's surface water resources. Table 1 shows the condition of the main catchments. Currently, the government has a challenge in agricultural development sector and growth of the country's economic status [14].

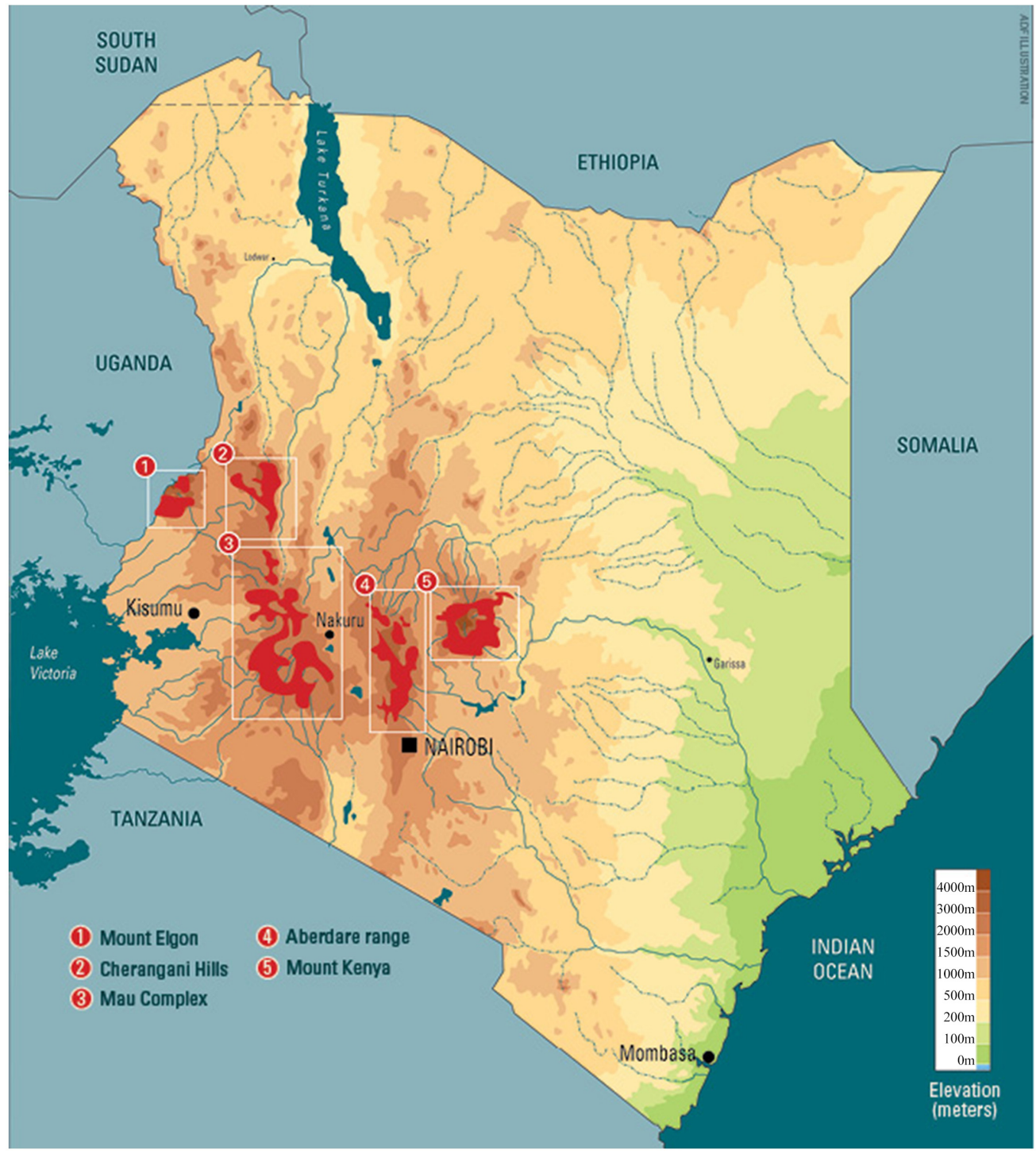

Figure 1. Kenya's water towers [13]. 
Table 1. Status of the main water catchment areas in Kenya [18].

\begin{tabular}{ccccc}
\hline Watershed name & $\begin{array}{c}\text { Catchment } \\
\text { area (ha) }\end{array}$ & Max. altitude (m) & $\begin{array}{c}\text { Gazetted forest } \\
\text { area (ha) }\end{array}$ & Main river \\
\hline Mt. Kenya & $1,253,959$ & 5199 & $\begin{array}{c}203,145 \\
(4 \% \text { cropland })\end{array}$ & Tana, Athi \\
Aberdare & $1,097,895$ & 4001 & $\begin{array}{c}104,078 \\
(11 \% \text { cropland })\end{array}$ & Ewaso Ngiro, Athi \\
Mau Forest Complex & 874,746 & 3098 & $\begin{array}{c}404,706 \\
(25 \% \text { cropland })\end{array}$ & Mara, Nyando, Yala \\
Cherangani Hills & 212,267 & 3365 & $\begin{array}{c}120,841 \\
(19 \% \text { cropland })\end{array}$ & Nzoia, Turkwell \\
Mt. Elgon & 249,996 & 4320 & $\begin{array}{c}72,547 \\
(15 \% \text { cropland })\end{array}$ & Nzoia, Turkwell \\
\hline
\end{tabular}

Figure 2 depicts that overall Kenya's renewable resources per capita [15]. Kenyans are consuming about 33 billion $\mathrm{m}^{3}$, of which their total renewable water resources only amount to 30.7 billion $\mathrm{m}^{3}$, this results in a difference of $2.7 \mathrm{~m}^{3}$ [16]. Additionally, some studies show that Kenya has $15 \%$ of its available water resources developed. This water is not easily accessible due to the increase in costs of water access or even technical challenges [17].

\section{Rundown of Typical Water Scarcity Indicators}

Since the late 1980s, when water scarcity was recognized to be a concern, many indicators have been developed to help in assessing water scarcity status adaptable to any area of the world [19]. Moreover, a comprehensive assessment of water quality and quantity status is important for global, regional, national, and local policy-relevant.

\subsection{The Falkenmark Indicator}

The Falkenmark Indicator requires the number of people living in a given spatial domain and the volume of water available in that domain [20]. The water volume available per person is then calculated in $\mathrm{m}^{3} / \mathrm{cap} /$ year. The indicator relies on population hence leading to the Water Crowding Index (WCI), which measures the number of people per unit of available water. A value of 1700 $\mathrm{m}^{3} / \mathrm{cap} /$ year of renewable freshwater was suggested to be the threshold for water scarcity below which social stress and high competition for water emerge [21]. If water availability falls below $1000 \mathrm{~m}^{3} / \mathrm{cap} /$ year then the area experiences high water scarcity while below $500 \mathrm{~m}^{3} / \mathrm{cap} /$ year is absolute scarcity. This indicator disregards temporal variability and some important drivers of demand which are related to economic growth, lifestyle as well as technological developments [22]. Management practices and infrastructure are not contemplated by the index, therefore, the simple threshold does not reflect the true spatial distribution of demand within the domains over which the index is normally calculated. 


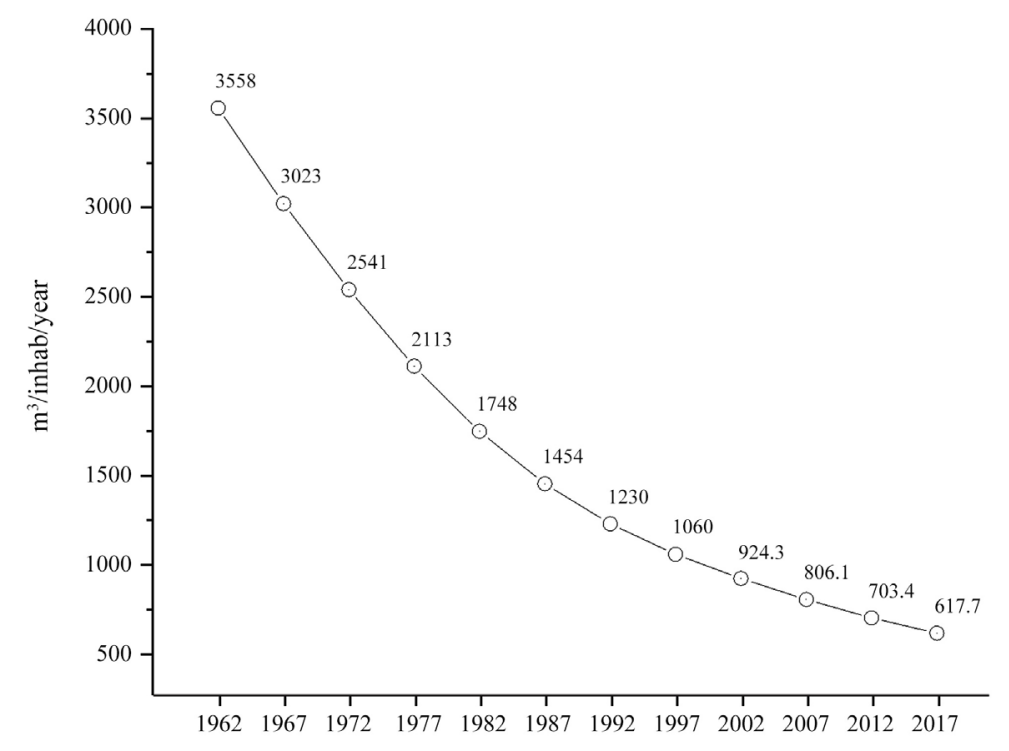

Figure 2. Total renewable resources per capita in Kenya [15].

In Kenya, population growth has been used as the main determinant of water scarcity. However, this is quite deceptive since population growth is not only the aspect that influences water use. Such a scenario is menacing and may lead to skewed policy formulation.

\subsection{Water Use to Availability Ratio}

The relationship between water use and water availability (criticality ratio) evaluates the amount of water used and relates it to the available renewable water resources [23]. This model is used spatially explicitly on a global scale with a high-level spatial resolution [24]. Water use refers to either water consumption or water withdrawals. Water consumption quantifies the amount that is removed from rivers, lakes, or groundwater sources and evaporated into the atmosphere while for the case of water withdrawal, it quantifies the amount of water that is withdrawn from these sources, where some part eventually returns to the system by either leakage or return flow. Previous studies have used the existing water scarcity withdrawal to indicate water use [25]. According to [26], water consumption is much smaller compared to withdrawal, the ratio of consumption to average available renewable water resources usually specifies an unrealistic low level of water scarcity. Therefore, as per this model, a high level of water stress occurs given that water withdrawal exceeds $40 \%$ of the available water resources [23]. However, parts of water withdrawal return to the water bodies, and the actual proportion of the return flow vary across regions. It obvious this depends on the natural, social-economic, and various technical conditions. Therefore, using $40 \%$ as a water scarcity threshold, may not be consistent in specifying the status of water scarcity across different regions.

\subsection{Physical and Economic Water Scarcity}

The International Water Management Institute (IWMI) used this indicator for 
evaluating water scarcity by combining both physical and economic water scarcity [27]. IWMI considers the amount of water supply from renewable freshwater resources for human consumption while accounting for the existing water infrastructure such as desalinization plants and water stored in reservoirs. This index considers an individual country's potential to develop water infrastructure as well as improving irrigation water use efficiency. Their analysis yielded five-country groupings. Country groupings were used to define whether countries are either economic or physical water stress [28]. Physical scarcity happens where countries are not able to meet the estimated water demand in 2025, even after accounting for the national adaptive capacity while economic scarcity occurs when countries have sufficient renewable water resources but in order to make the resources available for consumption by 2025, they are expected to have investments mostly in water infrastructure. The limitation of the IWMI model is it's considered to be more complex and time-consuming in computation. However, the interpretation is said to be less intuitive hence less attractive for presentation to public or policy audience [28].

\subsection{Water Poverty Index}

The Water Poverty Index (WPI) examines the link in the physical extent of water availability, ease of abstraction and the level of community well-being [29]. It features five key components such as water quantity, quality and variability; water access for human consumption; water use for different purposes; peoples' ability to water management; and environmental components. The WPI evaluates the situation facing poor water endowments along with poor adaptive capacity. The WPI is calculated with the weighted average components, each of which is first standardized so that it falls in the range 0 to 100; thus the resulting WPI value is also in the range of 0 and 100, representing the lowest and the highest level of water poverty [30]. The indicator has the benefit of comprehensiveness. Its implementation is hampered by its complexity and lack of adequate information for some components required for establishing the indicator on large scale [28].

\section{Spatial Distribution of Water Scarcity}

Uneven distribution of water may be linked to precipitation, the geographical landscapes, availability, population distribution as well as socio-economic factors. However, variation in the water supply occurs when the supply during dry seasons does not meet the demand, and this could be with the total quantity and quality supplied and the reliability of supply [31] [32]. From previous studies done in 2014, 31.6\% of Kenya's population use unimproved drinking-water sources, involving $7.3 \%$ of the population use unprotected dug wells, $4.4 \%$ unprotected springs, $1.5 \%$ tanker trucks or carts with drum, and $18.4 \%$ surface water [33]. The higher number (85.7\%) of the urban population have access to improved drinking-water sources, whilst about half $(41.5 \%)$ of the rural population 
use unimproved drinking-water sources [33]. Unimproved water sources such as unprotected dug wells and surface water (that includes untreated water from rivers, streams, ponds, and lakes) have been illustrated as shown in Figure 3 [33]. However, areas of Western and Central Kenya have a higher unprotected dug wells occupancy and surface water is sparsely distributed in Eastern Kenya [33].

\section{Challenges and Impacts of Water Scarcity in Kenya}

Water management is a major challenge in Kenya across the decades. However, water scarcity has led to poor sanitation and poor hygiene collectively posing substantial health risks, particularly in low-income regions and eventually contributing to the emergence of some diseases. Water shortage in Kenya is largely pronounced in rural areas and largely in the Arid and Semi-Arid Lands (ASALs) which has led to the strain on women and children having the task of searching for water especially for domestic use. Water shortage has caused children to be more vulnerable by affecting their education life whereby in some regions, children miss out from attending school in search of water. Children living in low-income areas and especially in informal settlements are vulnerable; hence resulting to morbidity and mortality in children due to diarrhea and consumption of unsafe water. Reports done by the Disease Control Priority Project shows that $90 \%$ of the deaths can be avoided through improved sanitation, hygiene and water supply.

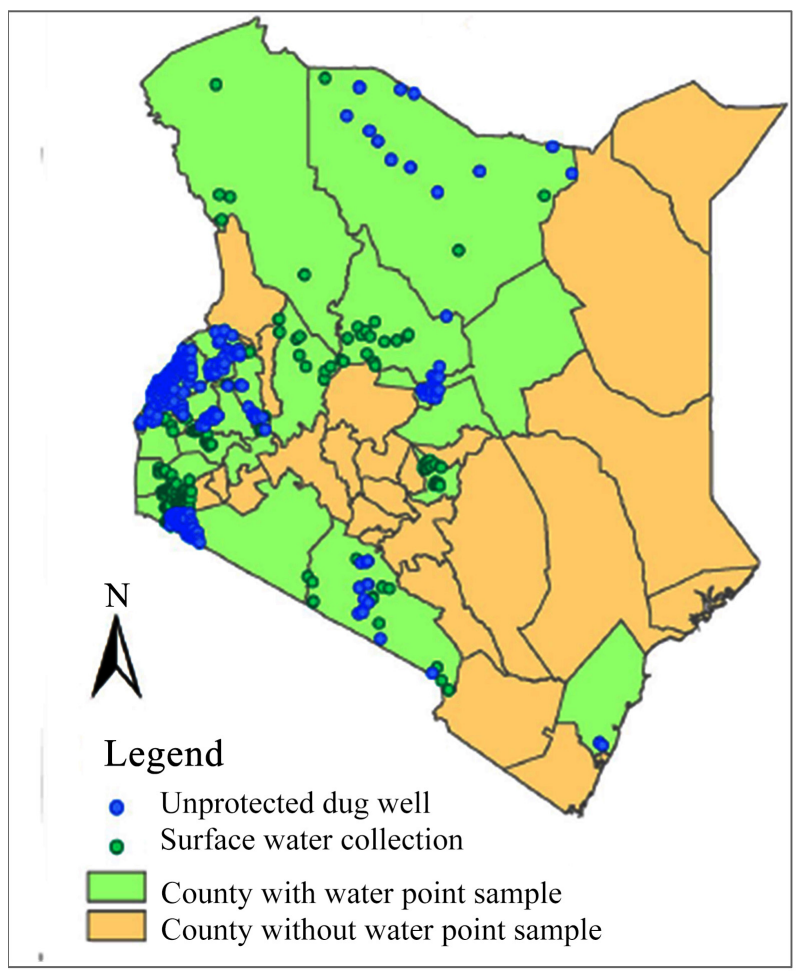

Figure 3. Distribution of unprotected dug wells and surface water points in various regions across Kenya [33]. 


\subsection{Population Growth and Urbanization}

Kenya's population has been rising since 1948 to date (Figure 4) [34]. The population growth rate estimate is at least $2.6 \%$ per annum. Therefore, this implies that the population is predicted to grow to about 53 million by the end of the plan period in 2022 as per the projections of the Kenya National Bureau of Statistics. Kenya highly depends on natural resources and in particular agriculture, the growing population will face considerable pressure on water resources including encroachment of marginal lands to cater for human settlement. It is projected that $70 \%$ of the world's population may live in urban areas by 2050 [35]. Population growth continues to increase the water demand in the agricultural sector, industrial and domestic uses (Figure 5) [36]. Lack of access to clean water is one of the major challenges among the urban population in Kenya. Rapid urbanization has caused many people across the country unable to cope with the high demand for a clean and sufficient water supply.

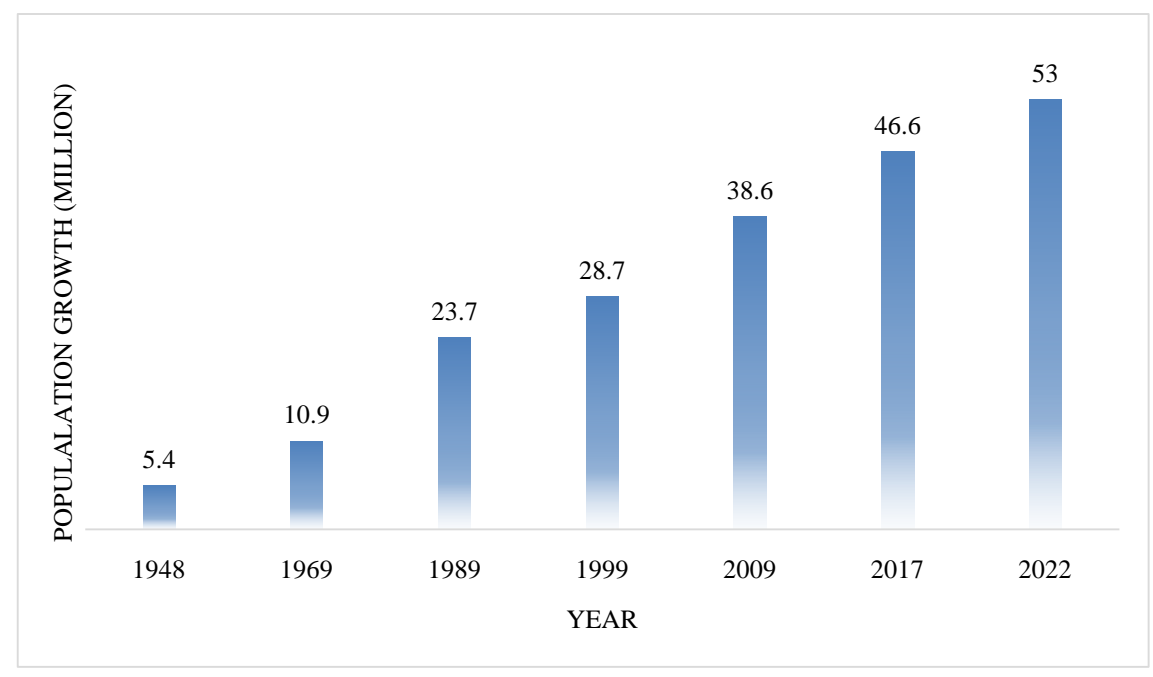

Figure 4. Population growth trends in Kenya [34].

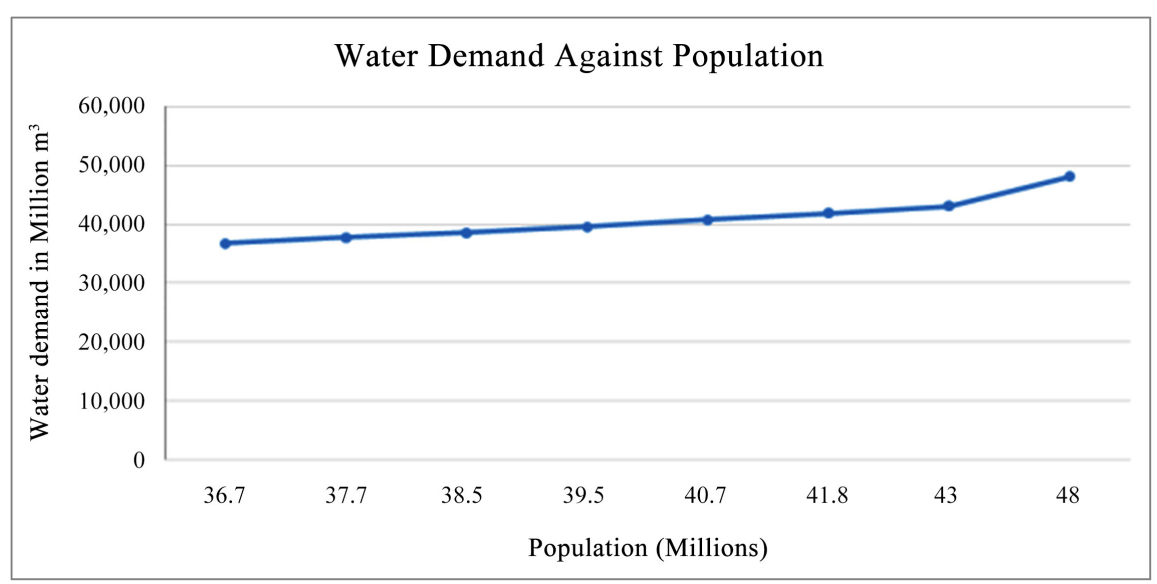

Figure 5. Population growth in relation to total water demand for all sectors in Kenya [36]. 


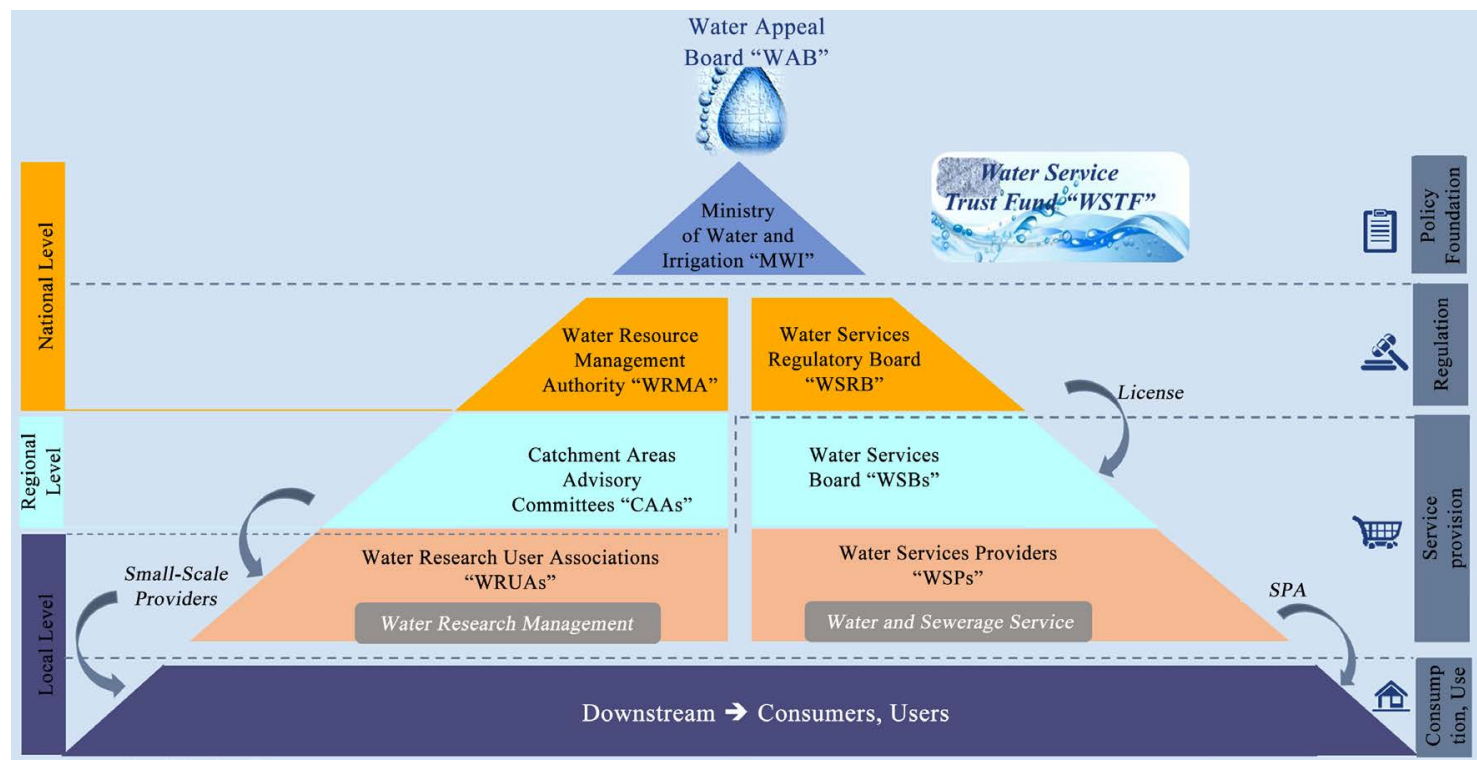

Figure 6. Institutional setup for water management and provision in Kenya under Water Act 2002 (Adapted from [43] [44]).

\subsection{Water Pollution}

Water pollution has affected water quality due to various pollutants such as chemical, microbiological, thermal pollutants among others [37]. Chemical contamination may result from the presence of excess nutrients, heavy metal contents, salinity, acidification, and changes in sediment loads. However, microbiological contamination can result from the presence of either bacteria, viruses or protozoa present in water. Studies indicate that $32.5 \%$ of industries and $14 \%$ of agriculture are key contributors to the economic development of a population [38]. In contrast, $80 \%$ of water pollution and contamination come from these two sectors. Growth and development of agricultural sector in Kenya have led to an increase in the use of fertilizers. Agrochemicals eventually enter into water bodies causing pollution. Furthermore, some industrial and the country government's sewage plants may release partially treated or completely untreated effluents into the surface water sources containing high levels of toxic substances. As a result, this affects most people living in the urban informal settlements due to lack of access to clean water hence causing disease outbreaks affecting their health and livelihoods.

\subsection{Encroachment of Water Catchment}

Kenya's forest cover is currently at $6.99 \%$ of its land area which is below the Kenyan constitutional requirement of $10 \%$ [39]. Kenya's forests support five major catchment areas namely: Mount Kenya, Aberdare Range, Cherangani Hills, Mt. Elgon and Mau Forest Complex.

These water sources are "Kenya's water towers" as they form the upper catchment of all except one main river in Kenya. These water catchment areas with a coverage of only $2 \%$ of the total land area provide important services to the 
economy of Kenya as well as supporting transboundary water bodies, underlying their regional and international importance [40]. Some activities like poor farming practices and deforestation lead to the degradation of these water catchment areas. The catchment degradation has led to increased surface runoff, flash floods, reduction in infiltration, erosion and siltation among others. Protection of the catchment environment is vital for the security and sustainability of urban water supply and the minimization of water scarcity. These water towers have been damaged severely due to human encroachment, agricultural activities, rapid human population growth, illegal logging, charcoal burning, water pollution and other illegal abstractions by some industries and urban settlements. Land cover changes may cause negative impacts both within the forest and downstream in the form of water shortages, health problems, and desertification as well.

\section{Solutions to Water Scarcity: Sustainable and Integrated Approaches}

Future prospects are important for the type of solutions that would be appropriate in solving water scarcity issues in Kenya. Different techniques have been used to solve the issue of water scarcity. Water recycling and reuse are some of the reliable techniques which have been recognized as adaptive solutions to water scarcity, considering water reuse has the concept of a circular economy. However, the adoption of advanced technological solutions and practices that improve water use efficiency by users should be a primary goal for water management to reduce water loss, support the sustainability of water resources, and increase the economic profitability of water.

\subsection{Water Scarcity and SDG 6: Clean Water and Sanitation}

Clean water and sanitation remain vital for the 2030 Agenda for Sustainable Development, yet Kenya has achieved less when it comes to ensuring the availability and sustainable management of water and sanitation for all [41]. The Sustainable Development Goal 6, target 6.4 relates to water use and scarcity, where it illustrates that: "By 2030, substantially increasing water-use efficiency across all sectors and ensuring the sustainable withdrawals and supply of fresh water in order to address water scarcity and substantially reduce the number of people affected by water scarcity." [42]. The SDG guidance notes that a "high level of water stress can have negative impact on the economic development, increased competition and have potential conflict among different users, which calls for the effective supply and demand management policies as well as an increase in water-use efficiency. The key point for water managers and policymakers is that the portion of overall water that can effectively be used to meet demand at the right place can be enhanced by implementing appropriate policies or interventions, such as reducing the direct surface runoff through catchment restoration, water transport, and water storage technologies. 


\subsection{Water Policy and Implications}

Water Act was enacted in Kenya to mainly provide the management, conservation, use and the control of water resources and for the regulation of rights to water usage; provision of regulations and management of water supply and sewerage services; to repeal the Water Act (Cap. 372) and provisions of Local Government Act; and other related purposes. The Act aims at improving the living standards among different people by ensuring proper access to water services. However, it provides management and development of water resources supply and sewerage development, intending to conserve, protect available water resources and allocate suitably and economically as well as supplying water in sufficient quantities to meet the various water needs while ensuring safe disposal of water. This Act therefore clearly outlines methods and ways of ensuring that water is availed to all and its provision is ensured and managed adequately and sustainably.

Kenya has enacted policies at the national and regional levels to guide the conservation and management of its water resources. Crucial reforms have been set up in the water sector that culminates in the enactment of the Water Act of 2002 and the consequent formation of various Water Resource Users Associations (WRUAs) by the Water Resource Management Authority. The National Policy on Water Resources Management and Development through the Water Act 2002 guides the water resources management and the provision of water services in the country (Figure 6) [43] [44]. The Water Sector Trust Fund (WSTF) was established under the Water Act and restructured from the Water Services Trust Fund to Water Sector Trust Fund (WSTF). The mandate of WSTF is financing water and sanitation services in the country. The establishment of these institutions aims to organize the water sector in the country and by ensuring that the anticipated universal access to water is achieved.

The Water Act 2016 establishes a Water Resources Authority which is a regulatory authority mandated to perform the following functions: 1) Formulation and the enforcement standards, procedures and regulations for the management and use of water resources and flood mitigation; 2) Regulation of water resources use and management; 3) Receiving water permit applications for water abstraction, water use and recharge and decision making, issue, vary water permits; and enforce the conditions of those permits.

\subsection{Integrated Approaches to Water Scarcity}

Based on the present water demand and the future national development plans, Kenya would face a huge gap between water demand and the available water supply in the years to come. Sustainable development and management of water resources is therefore critical and should effectively be addressed by respective government institutions, various development partners, civil society groups and the private sectors. Kenya can boost its water productivity in a short-term period by harmonizing and strengthening the existing and established multi-level water 
management bodies such as the Catchment Area Advisory Committees, Water Users Associations and Water Resource Management Authority. In order to improve the availability of a sustainable water supply, conservation and the restoration of national water catchment areas, as well as a strategic investment in the additional dams, is key. In addition, the construction of efficient water treatment plants should be a priority for urban water and sewerage companies in order to facilitate water treatment and re-use. Green or nature-based solutions can help in the improvement of water supply and shortage, thus increasing water availability [45]. This is important particularly in the current world considering expectations that water shortage would worsen in Sub-Saharan Africa as a result of climate change drought risk causing the decline of water levels of dams and freshwater supply sources [46] [47]. Water scarcity and security issues will be exacerbated by recent trends of climate variability and the consequent rise in droughts. Thus, climate-resilient water resource management will require an integrated strategy to ensure resilience for water-related policy making to address both short- and long-term impacts of climate change by balancing robustness with flexibility. With future uncertainties and the likelihood of other potential infectious disease outbreaks, there is a need for robust adaptation options that have the primary objective of supporting sustainable water resource use.

\section{Conclusion}

Access to clean and safe drinking water is a problem faced by almost half of Kenya's population. The demand for adequate and clean water supply is rising due to the increasing population, and in the response to global aim in the achievement to meet Sustainable Development Goals (SDGs). To address the water scarcity issues, a strategic plan has been put in place through the construction of large and medium dams to store water as well as investing in groundwater storage through managed aquifer recharge by making use of stormwater generated during the rainy seasons. Some challenges such as forest fragmentation, poor water management and contamination of water sources are possibly solvable, the frequency and droughts and floods occurrence are an indicator of climatic change which is likely to become more unpredictable in the future.

\section{Acknowledgements}

The first author would wish to thank the third author for the invaluable support in the compilation of this paper.

\section{Conflicts of Interest}

The authors declare no conflicts of interest regarding the publication of this paper.

\section{References}

[1] Chellaney, B. (2013) Water, Peace, and War: Confronting the Global Water Crisis. 
Rowman \& Littlefield, Lanham. https://rowman.com/ISBN/9781442221390/Water-Peace-and-War-Confronting-the -Global-Water-Crisis

[2] Bakker, K. (2012) Water Security: Research Challenges and Opportunities. Science, 337, 914-915. https://doi.org/10.1126/science.1226337

[3] World Water Assessment Programme (United Nations) and UN-Water. (2009) Water in a Changing World. Earthscan, London.

[4] Showers, K.B. (2002) Water Scarcity and Urban Africa: An Overview of Urban-Rural Water Linkages. World Development, 30, 621-648. https://doi.org/10.1016/S0305-750X(01)00132-2

[5] Engel, K., Jokiel, D., Kraljevic, A., Geiger, M. and Smith, K. (2011) Big Cities, Big Water, Big Challenges: Water in an Urbanizing World. World Wildlife Fund, Koberich.

https://www.indiawaterportal.org/sites/default/files/iwp2/Big Cities Big Water Bi g Challenges 2011.pdf

[6] Jones, J.A.A. (2014) Water Sustainability: A Global Perspective. Routledge, Abingdon-on-Thames.

[7] Ondigo, D.A., Kavoo, A.M. and Kebwaro, J. (2018) Water Resources and Management under Increasing Urban Demography: A Kenyan Perspective-A Review. Journal of Water Resource and Protection, 10, 919-938. https://doi.org/10.4236/jwarp.2018.109054

[8] Kibuika, F.M. and Wanyoike, D (2012) Assessment of Factors Affecting Sustainability of Rural Water Supply Schemes in Nyandarua County, Kenya: A Case of Kangui Water Scheme. International Journal of Science and Research (IJSR), 3, 578-584.

[9] Wakhungu, M.J. (2019) An Ethnography of Policy: Water Reuse Policy in Kenya. Water Policy, 21, 436-448. https://doi.org/10.2166/wp.2019.160

[10] Jiménez, B. and Asano, T. (2008) Water Reuse: An International Survey of Current Practice, Issues and Needs. IWA, London. https://doi.org/10.2166/9781780401881

[11] Seckler, D., Barker, R. and Amarasinghe, U. (1999) Water Scarcity in the Twenty-First Century. International Journal of Water Resources Development, 15, 29-42. https://doi.org/10.1080/07900629948916

[12] Crafford, J., Strohmaier, R., Muñoz, P. and Oliveira, T. (2012) The Role and Contribution of Montane Forests and Related Ecosystem Services to the Kenyan Economy. United Nations Environment Programme (UNEP), Nairobi.

[13] Africa Defense Forum (2019) Kenya's Environmental Warriors. Last Accessed: Decembre 23, 2020

https://adf-magazine.com/2019/10/kenyas-environmental-warriors/

[14] Habitat, U. (2013) State of the World's Cities 2012/2013: Prosperity of Cities. Routledge, London, 2013.

[15] Knoema (2020) Kenya-Total Renewable Water Resources per Capita. Last Accessed: December 30, 2020. https://knoema.com/atlas/Kenya/topics/Water

[16] Mugera, W.N. (2015) Factors Influencing Crop Production in Irrigation Schemes in the Arid and Semi Arid Lands of Kenya: The Case of Hola Irrigation Scheme, Tana River County, Kenya. University of Nairobi, Nairobi.

[17] Herrero, M.T., et al. (2010) Climate Variability and Climate Change and Their Impacts on Kenya's Agricultural Sector. ILRI, Nairobi.

[18] Chepyegon, C. and Kamiya, D. (2018) Challenges Faced by the Kenya Water Sector 
Management in Improving Water Supply Coverage. Journal of Water Resource and Protection, 10, 85-105. https://doi.org/10.4236/jwarp.2018.101006

[19] Liu, J., Yang, H., Gosling, S.N., Kummu, M., Flörke, M., Pfister, S., et al. (2017) Water Scarcity Assessments in the Past, Present and Future. Earths Future, 5, 545-559. https://doi.org/10.1002/2016EF000518

[20] Falkenmark, M., Lundqvist, J. and Widstrand, C. (1989) Macro-Scale Water Scarcity Requires Micro-Scale Approaches: Aspects of Vulnerability in Semi-Arid Development. Natural Resources Forum, 13, 258-267. https://doi.org/10.1111/j.1477-8947.1989.tb00348.x

[21] Falkenmark, M., Rockstrom, J. and Rockström, J. (2004) Balancing Water for Humans and Nature: The New Approach in Ecohydrology. Earthscan.

[22] Savenije, H. (2000) Water Scarcity Indicators; the Deception of the Numbers. Physics and Chemistry of the Earth, Part B: Hydrology, Oceans and Atmosphere, 25, 199-204. https://doi.org/10.1016/S1464-1909(00)00004-6

[23] Alcamo, J. and Henrichs, T. (2002) Critical Regions: A Model-Based Estimation of World Water Resources Sensitive to Global Changes. Aquatic Sciences, 64, 352-362. https://doi.org/10.1007/PL00012591

[24] Wada, Y., Wisser, D. and Bierkens, M. (2014) Global Modelling of Withdrawal, Allocation and Consumptive Use of Surface Water and Groundwater Resources. Earth System Dynamics, 5, 15-40. https://doi.org/10.5194/esd-5-15-2014

[25] Oki, T. and Kanae, S. (2006) Global Hydrological Cycles and World Water Resources. Science, 313, 1068-1072. https://doi.org/10.1126/science.1128845

[26] Munia, H., Guillaume, J., Mirumachi, N., Porkka, M., Wada, Y. and Kummu, M. (2016) Water Stress in Global Transboundary River Basins: Significance of Upstream Water Use on Downstream Stress. Environmental Research Letters, 11, 014002. https://doi.org/10.1088/1748-9326/11/1/014002

[27] Seckler, D., Amarasinghe, U., Molden, D., de Silva, R. and Barker, R. (1998) World Water Demand and Supply, 1990 to 2025: Scenarios and Issues. International Water Management Institute, 19, p. 50.

http://www.iwmi.cgiar.org/Publications/IWMI_Research_Reports/PDF/PUB019/R EPORT19.PDF

[28] Rijsberman, F.R. (2006) Water Scarcity: Fact or Fiction? Agricultural Water Management, 80, 5-22. https://doi.org/10.1016/j.agwat.2005.07.001

[29] Sullivan, C., et al. (2000) The Development of a Water Poverty Index: A Feasibility Study.

[30] Sullivan, C.A., Meigh, J.R. and Giacomello, A.M. (2003) The Water Poverty Index: Development and Application at the Community Scale. Natural Resources Forum, 27, 189-199. https://doi.org/10.1111/1477-8947.00054

[31] Fremlin, K.M., et al. (2020) Trophic Magnification of Legacy Persistent Organic Pollutants in an Urban Terrestrial Food Web. Science of the Total Environment, 714, e136746. https://doi.org/10.1016/j.scitotenv.2020.136746

[32] Eni, D.I., Digha, O.N. and Moses, A. (2015) Spatio-Temporal Variability in Domestic Water Demand and Supply in Calabar Metropolis. International Journal of Research in Environmental Science, 1, 20-29.

[33] Yu, W., Wardrop, N.A., Bain, R.E.S., Alegana, V., Graham, L.J. and Wright, J.A. (2019) Mapping Access to Domestic Water Supplies from Incomplete Data in Developing Countries: An Illustrative Assessment for Kenya. PLoS ONE, 14, e0216923. https://doi.org/10.1371/journal.pone.0216923 
[34] KNBS (2019) 2019 Kenya Population and Housing Census, Volume II: Distribution of Population by Administrative Units. KNBS, Nairobi.

[35] Larsen, T.A., Hoffmann, S., Lüthi, C., Truffer, B. and Maurer, M. (2016) Emerging Solutions to the Water Challenges of an Urbanizing World. Science, 352, 928-933. https://doi.org/10.1126/science.aad8641

[36] Ministry of Water and Sanitation (2018) Strategic Plan 2018-2022. Ministry of Water and Sanitation, Nairobi, $85 \mathrm{p}$.

[37] Carr, G.M. and Neary, J.P. (2008) Water Quality for Ecosystem and Human Health. UNEP/Earthprint.

[38] World Water Assessment Programme (United Nations) (2003). Water for People, Water for Life: The United Nations World Water Development Report: Executive Summary.

[39] Ng'ang'a, L.M. (2014) Exploring Population Density and Forest Cover Linkages: Evidence from Kenya. University of Nairobi, Nairobi.

[40] Mogaka, H., Gichere, S., Davis, R. and Hirji, R. (2005) Climate Variability and Water Resources Degradation in Kenya: Improving Water Resources Development and Management. The World Bank, London.

https://doi.org/10.1596/978-0-8213-6517-5

[41] Nhamo, G., Nhemachena, C. and Nhamo, S. (2019) Is 2030 Too Soon for Africa to Achieve the Water and Sanitation Sustainable Development Goal? Science of The Total Environment, 669, 129-139. https://doi.org/10.1016/j.scitotenv.2019.03.109

[42] UN (United Nations) (2019). The Sustainable Development Goals Report, p. 64 https://unstats.un.org/sdgs/report/2019/The-Sustainable-Development-Goals-Repo rt-2019.pdf

[43] Rampa, F. (2011) Analysing Governance in the Water Sector in Kenya. Discussion Paper 124, Maastricht: European Centre for Development Policy (Discussion Paper No. 124).

https://ecdpm.org/wp-content/uploads/2013/11/DP-124-Analysing-Governance-W ater-Sector-Kenya-2011.pdf

[44] Chakava, Y., Franceys, R. and Parker, A. (2014) Private Boreholes for Nairobi's Urban Poor: The Stop-Gap or the Solution? Habitat International, 43, 108-116. https://doi.org/10.1016/j.habitatint.2014.01.012

[45] Naik, P.K. (2016) Water Crisis in Africa: Myth or Reality? International Journal of Water Resources Development, 33, 326-339. https://doi.org/10.1080/07900627.2016.1188266

[46] Mora, C., Frazier, A.G., Longman, R.J., Dacks, R.S., Walton, M.M., Tong, E.J., et al. (2013) The Projected Timing of Climate Departure from Recent Variability. Nature, 502, 183-187. https://doi.org/10.1038/nature12540

[47] Naik, P.K. (2017) Water Crisis in Africa: Myth or Reality? International Journal of Water Resources Development, 33, 326-339. https://doi.org/10.1080/07900627.2016.1188266 